\title{
Calcium Inhibition of Polyacrylamide Gel Hydration Is Partially Reversible by Potassium
}

\author{
Daniel C. Bowman \\ Department of Plant Science, University of Nevada, Reno, NV 89557 \\ Richard Y. Evans \\ Department of Environmental Horticulture, University of California, \\ Davis, CA 95616
}

Additional index words. hydrogel, soil amendment, cation exchange

\begin{abstract}
Hydration of a commercial hydrophilic polyacrylamide gel in 20 meq $\mathrm{Ca}\left(\mathrm{NO}_{3}\right)_{2} /$ liter was reduced to $<\mathbf{1 0 \%}$ of the maximum hydration in deionized water. Repeated soaking with deionized water to remove soluble salts restored hydration to $\approx 30 \%$ of maximum. Incorporating $\mathrm{KNO}_{3}$ at concentrations ranging from 5 to 40 meq.liter ${ }^{-1}$ with the $\mathrm{Ca}\left(\mathrm{NO}_{3}\right)_{2}$ in the hydration solution partially reversed the $\mathrm{Ca}^{2+}$ inhibition of hydration following repeated soaking. Potential hydrogel hydration increased to $50 \%$ of maximum with 40 meq $\mathrm{K}^{+} /$liter. Potassium nitrate supplied separately following hydration in $\mathrm{Ca}\left(\mathrm{NO}_{3}\right)_{2}$ was much more effective at reversing $\mathrm{Ca}^{2+}$ inhibition of hydrogel hydration than joint application. Potential hydrogel hydration (following repeated soaking) was doubled after treatment with 5 meq $\mathrm{KNO}_{3}$ /liter and reached $77 \%$ of maximum at 40 meq $\mathrm{KNO}_{3}$ /liter.
\end{abstract}

Hydrophilic polyacrylamide gels (hydrogels) are marketed as amendments to increase the water-holding capacity of container media and field soils, based on their ability to absorb up to 1500 times their weight in water (Johnson, 1984). The cross-linked polyacrylamide hydrogels commonly available in the horticultural trade are capable of absorbing $>400 \mathrm{ml}$ of water per gram of hydrogel. The presence of salts in solution, however, severely restricts hydrogel hydration (Bowman et al., 1990; Foster and Keever, 1990; James and Richards, 1986; Lamont and O'Connell, 1987; Wang and Gregg, 1990). Solutions containing salts of the monovalent cations $\mathrm{K}+$ and $\mathrm{NH}_{4}^{+}$or the divalent cations $\mathrm{Ca}^{2+}$ and $\mathrm{Mg}^{2+}$, at $20 \mathrm{meq} \cdot \mathrm{liter}^{-1}$, reduced hydrogel hydration by $>75 \%$ and $90 \%$ of maximum, respectively (Bowman et al., 1990). The inhibition of hydration caused by $\mathrm{KNO}_{3}$ was completely reversed by rinsing the hydrogels with deionized water (DI), whereas the inhibition caused by $\mathrm{Ca}\left(\mathrm{NO}_{3}\right)_{2}$ was only partially reversible. We found no reports of methods by which the $\mathrm{Ca}^{2+}$ inhibition of hydrogel hydration might be removed. We report here the results of two

Received for publication 22 Oct. 1990. The cost of publishing this paper was defrayed in part by the payment of page charges. Under postal regulations, this paper therefore must be hereby marked advertisement solely to indicate this fact. experiments examining the effects of $\mathrm{K}+$ on a calcium-inhibited hydrogel.

Experiment 1 examined the effect on hydrogel hydration of $\mathrm{K}+$ supplied in solution with $\mathrm{Ca}^{2+}$. Samples $(1 \mathrm{~g})$ of a commercial polyacrylamide hydrogel (Broadleaf P-4, Broadleaf Industries, San Diego, Calif.), with a particle size of 1 to $2 \mathrm{~mm}$, were each added to either 1 liter of DI or 1 liter of 20 meq $\mathrm{Ca}\left(\mathrm{NO}_{3}\right)_{2}$ /liter, plus $\mathrm{KNO}_{3}$ at $0,5,10,20$, or 40 meq.liter ${ }^{-1}$, with three replicates per treatment. After $24 \mathrm{~h}$, the hydrated hydrogels were collected on a fine mesh screen and the excess solution was removed by blotting the bottom of the screen with a moist sponge. After weighing the samples, each was transferred to 1 liter of DI for $24 \mathrm{~h}$, then collected and reweighed. The samples were transferred daily for 3 days to fresh DI and reweighed to estimate the maximum potential hydration of the hydrogels.

Experiment 2 examined the ability of $\mathrm{K}^{+}$ to reverse the calcium inhibition of hydrogel hydration when the $\mathrm{KNO}_{3}$ solution was supplied after hydration of the hydrogel in a solution of $\mathrm{Ca}\left(\mathrm{NO}_{3}\right)_{2}$. Samples (1 g) of the hydrogel were hydrated for $24 \mathrm{~h}$ in 1 liter of 20 meq $\mathrm{Ca}\left(\mathrm{NO}_{3}\right)_{2} /$ liter. The samples were then collected, weighed, and transferred to 1-liter solutions of $\mathrm{KNO}_{3}$ at $0,5,10,20$, and $40 \mathrm{meq} \cdot$ liter $^{-1}$. The hydrogel samples were weighed again after $24 \mathrm{~h}$, then transferred to 1 liter of DI. As in Expt. 1, this 


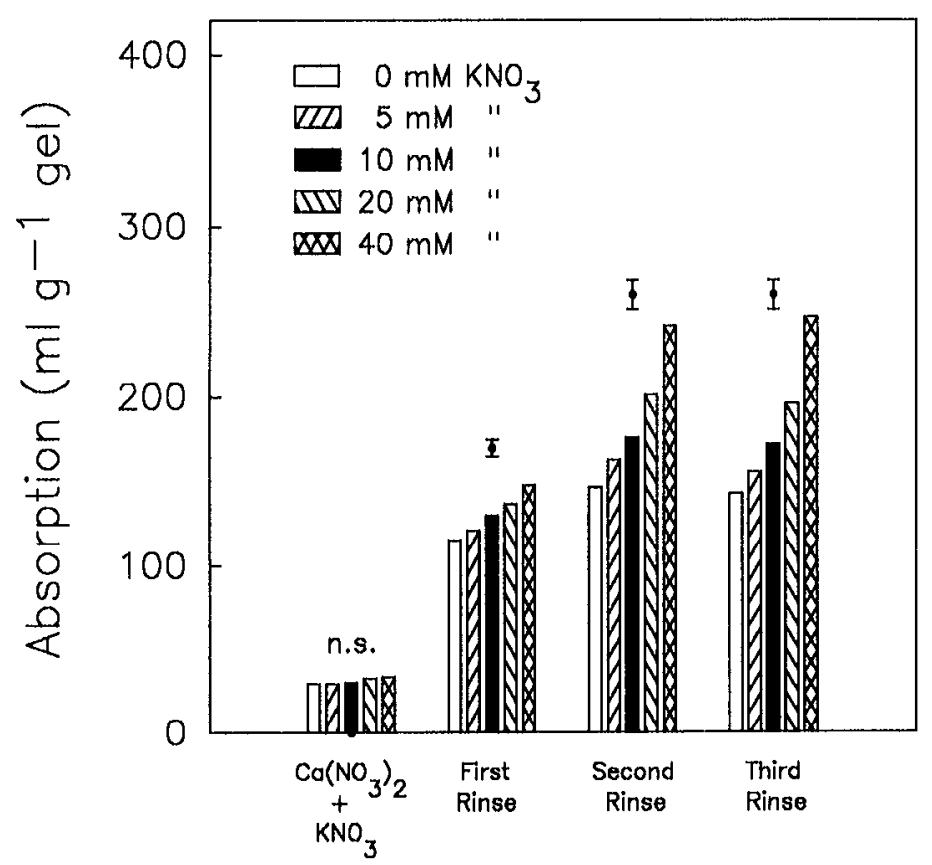

Fig. 1. The effect of $\mathrm{KNO}_{3}$, supplied with $\mathrm{Ca}\left(\mathrm{NO}_{3}\right)_{2}$ in the hydrating solution, on the hydration potential of a polyacrylamide hydrogel (Expt. 1). Vertical bars represent LSD at $P=0.05(\mathrm{n}=3)$.

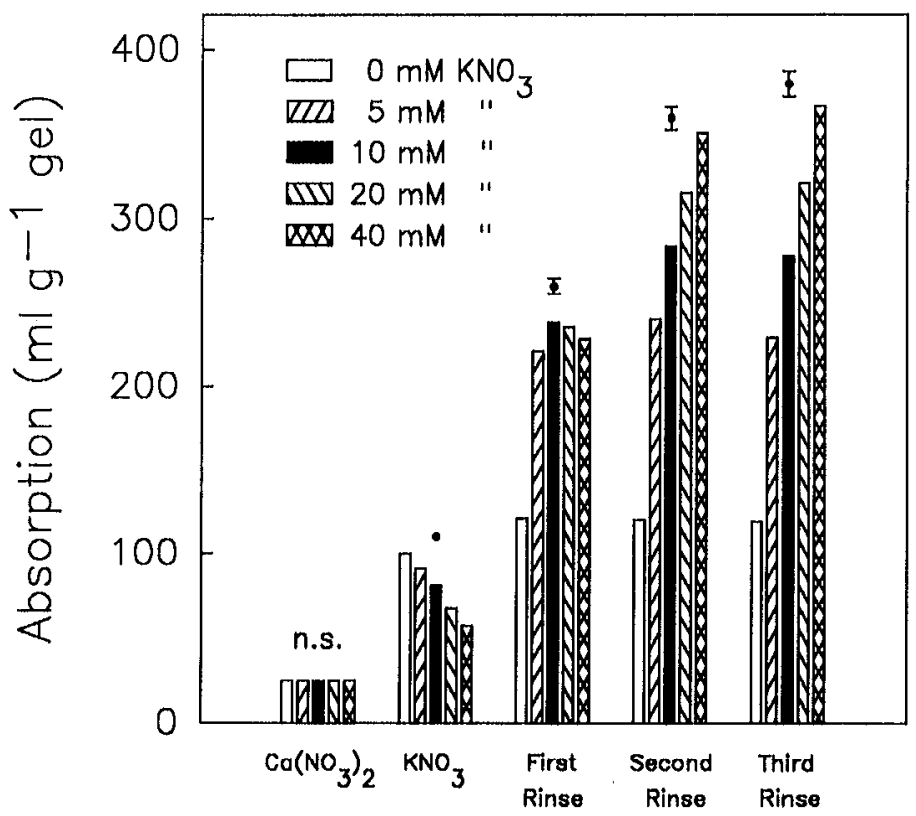

Fig. 2. The effect of $\mathrm{KNO}_{3}$, supplied after gels were hydrated in $\mathrm{Ca}\left(\mathrm{NO}_{3}\right)_{2}$, on the hydration potential of a polyacrylamide hydrogel (Expt. 2). Vertical bars represent LSD at $P=0.05(\mathrm{n}=3)$.

transfer to DI and reweighing was repeated daily for 3 days.

After a 24-h soaking in DI, the hydrogel had absorbed water at $420 \mathrm{ml} \cdot \mathrm{g}^{-1}$. whereas it absorbed only $30 \mathrm{ml} \cdot \mathrm{g}^{-1}$ in $20 \mathrm{meq}$ $\mathrm{Ca}\left(\mathrm{NO}_{3}\right)_{2}$ /liter (Fig. 1). Sequential soakings in DI increased hydration to $\approx 30 \%$ of maximum. Inclusion of $\mathrm{KNO}_{3}$ with $\mathrm{Ca}\left(\mathrm{NO}_{3}\right)_{2}$ in the hydration solution had no additional effect on the initial hydration of the hydrogel, but did provide some protection from calcium inhibition of hydration following soaking in DI. Hydration after the DI soaks increased linearly with $\mathrm{K}+$ concentration, from $\approx 150 \mathrm{ml} \cdot \mathrm{g}^{-1}$ hydrogel in $20 \mathrm{meq} \mathrm{Ca}\left(\mathrm{NO}_{3}\right)_{2} /$ liter to $250 \mathrm{ml} \cdot \mathrm{g}^{-1}$ hydrogel in $20 \mathrm{meq} \cdot$ liter $^{-1}$ $\mathrm{Ca}\left(\mathrm{NO}_{3}\right)_{2} /$ liter plus 40 meq $\mathrm{KNO}_{3} /$ liter.
Potassium ion was considerably more effective at restoring the hydration capacity of the hydrogel when it was supplied subsequent to the calcium salt (Fig. 2). Treatment with $\mathrm{K}+$ at 5 meq.liter ${ }^{-1}$ followed by soaking in DI doubled hydrogel hydration compared with the DI-soaked $\mathrm{Ca}\left(\mathrm{NO}_{3}\right)_{2}$, control. Treatment with 40 meq $\mathrm{K}+/$ liter followed by repeated soaking in DI, restored hydration of the hydrogel to $77 \%$ of maximum. Since the effect of $\mathrm{KNO}_{3}$ (in the absence of $\mathrm{Ca}^{2}$ ) is completely reversible by rinsing in DI (Bowman et al., 1990), the remaining inhibition observed here could be attributed to $\mathrm{Ca}^{2}+$ retained by the hydrogel.

These results underscore the importance of monovalent-divalent cation interactions in modulating polyactylamide gel hydration. Supplying $\mathrm{K}+$ in solution together with $\mathrm{Ca}^{2}+$ resulted in only a moderate increase in the hydration of the hydrogel after repeated soaking. In Expt. 1, where the hydrogel was hydrated in solutions of $\mathrm{Ca}\left(\mathrm{NO}_{3}\right)_{2}$ plus $\mathrm{KNO}_{3}$, the improvement in hydration with increasing $\mathrm{KNO}_{3}$ concentration is probably due to the competition between $\mathrm{K}+$ and $\mathrm{Ca}^{2}+$ for cation exchange sites in the hydrogel. In contrast, the large increases in hydration observed in Expt. 2 are probably the result of $\mathrm{K}+$ displacing $\mathrm{Ca}^{2}+$ on the hydrogel's cation exchange sites. Calcium would then be free to diffuse out of the hydrogel matrix. Eventually, an equilibrium would be reached between the activities of $\mathrm{Ca}^{2}+$ and $\mathrm{K}+$ in solution and exchangeable $\mathrm{Ca}^{2}+$ and $\mathrm{K}+$ on the cation exchange sites. The greater effectiveness of $\mathrm{KNO}_{3}$ when supplied subsequent to hydration of the hydrogel in $\mathrm{Ca}\left(\mathrm{NO}_{3}\right)_{2}$ was most likely a consequence of the much lower $\mathrm{Ca}^{2}+$ concentration in solution at equilibrium. Whether $\mathrm{KNO}_{3}$ was supplied together with $\mathrm{Ca}\left(\mathrm{NO}_{3}\right)_{2}$ or afterwards, its effect on calcium-inhibited hydrogel was evident only after repeated soaking in DI.

Based on these results, the potential horticultural benefits of hydrogel as a soil amendment might be enhanced by leaching gel-amended soils with water, or leaching first with a solution containing a potassium salt, followed by leaching with water. However, the application of such a practice in commercial horticulture may be limited. Most container media have a reservoir of calcium present in the solid phase, typically as calcium carbonate or dolomitic limestone. For such media, it would be extremely difficult to remove sufficient $\mathrm{Ca}^{2}+$ from the soil solution to permit rehydration of the hydrogel. Additionally, other container-soil amendments, such as Micromax, strongly inhibit hydrogel hydration (Foster and Keever, 1990), so it might be necessary to remove or exclude these as well. Finally, exhaustive leaching would be practical only at the end of the crop production cycle, when removal of the plant's nutrient supply may be unimportant.

We conclude that the inhibition of hydrogel hydration by calcium salts is partially reversible by application of solutions containing potassium salts, particularly when they are added after removal of $\mathrm{Ca}^{2}+$ from the solution bathing the hydrogel, and then only when followed by repeated soaking to remove soluble salts from the hydrogel. The need for thorough leaching of the hydrogel to restore hydration capacity may limit the practical application of this procedure in current horticultural production.

\section{Literature Cited}

Bowman, D.C., R.Y. Evans, and J.L. Paul. 1990 Fertilizer salts reduce hydration of polyacrylamide gels and affect physical properties of gelamended container media. J. Amer. Soc. Hort. Sci. 115:382-386.

Foster, W.J. and G.J. Keever. 1990. Water absorption of hydrophylic polymers (hydrogels) reduced by media amendments. J. Environ. Hort. $8: 113-114$ 
James, E.A. and D. Richards. 1986. The influence of iron source on the water-holding properties of potting media amended with waterabsorbing polymera. Scientia Hort. 28:201-208.

Johnson, M.S. 1984. Effect of soluble salts on water absorption by gel-forming soil conditioners. J. Sci. Food Agr. 35:1063-1066.

Lamont, G.P. and M.A. O'Connell. 1987.

Shelf-life of bedding plants as influenced by potting media and hydrogels. Scientia Hort.
31:141-149.

Wang, Y.T. and L.L. Gregg. 1987. Hydrophilic polymers-Their response to soil amendments and effect on properties of a soilless potting mix. J. Amer. Soc. Hort. Sci. 115:943-948. 